\title{
Application of Indigenous Knowledge in Natural Resources and Environment Conservation in Nepal
}

Ramesh Kumar Lama (M. Phil.)*

\begin{abstract}
Diversity, natural resources and indigenous knowledge are the wealth of Nepal. Nepalese indigenous people possesses large varieties in language, culture, traditions, art and literatures which can also be applied as knowledge system and can also be taken as indigenous knowledge. These indigenous knowledge are applicable not only in the continuation of beliefs, customs and traditions but also helpful in conservation of natural resources and environment. This paper aims to uncover the application of indigenous knowledge of some groups of indigenous people of Nepal and has applied descriptive and interpretive methods of study. The nature of data used in the study is qualitative. Most of practices are culturally and religiously important which are directly and indirectly helpful in environmental conservation but there is need of further scientific investigation and verification also.
\end{abstract}

Key words: Indigenous people, indigenous knowledge, custom, religion \& environment conservation.

\section{Introduction}

Nepal is a rich country on the basis of biodiversity and natural resources available due to its diverse geography, ecosystem and cultures. Nepal is leading $25^{\text {th }}$ and $11^{\text {th }}$ position on biodiversity in the world and Asia respectively. It is also claimed that it is the second largest country in water resources. It is reported that 118 types of ecosystem are naturally occurred in different geography (MoFSC, 2014). Sherpa (2005) states that each geography, ecosystem, biodiversity, bears a long historical attachment of native society as their cultural identity. With distinct language, religion, customs, folklore, culture,

${ }^{\star}$ Mr. Lama is a Lecturer at the Department of Rural Development, Patan Multiple Campus, TU, Lalitpur, Nepal.Email: ramshlama@gmail.com 
knowledge, ancient territory, fifty nine indigenous nationalities are legally recognized. In the past, Nepalese indigenous nationalities were excluded from main stream of national policies and were being legally apart from their ancient natural heritage, biodiversity, ethno-biology, ancient foods, medicines, agro biodiversity, skills, technology, knowledge, customary law/practice/values, traditional ethnics and sacred sites. Indigenous people are contributing own cultural wisdom on restoration, conservation, and wise use of biodiversity, natural resources and traditional knowledge's associated with their life from millennia but the present situation is quite different and the more inclusive policy measures have been adopted after the promulgation of interim constitution 2007 and Nepal's constitution 2015.

In Nepal, Indigenous peoples are residing on different geographic belts with traditional life styles are closely attached with ecosystem, biodiversity, natural resources, and environmental from ancient period of time. Indigenous societies of Nepal possess dynamic ancient epistemology, wisdom, knowledge, skills, technologies, endogenous or cosmological believe, folklore, customs oral tradition associate with nature, earth, biodiversity and natural resources.

Regarding the definition of Indigenous people, the international community has not adopted the common definition of indigenous peoples and the prevailing view today is that no formal universal definition is necessary for the recognition and protection of their rights. However, there have been attempts to outline the characteristics of indigenous peoples. The ILO's indigenous and tribal Peoples Convention, 1989 (art. 169) applies to:

i) Tribal peoples whose social, cultural and economic conditions distinguish them from other sections of the national community, and whose status is regulated wholly or partially by their own customs or traditions or by special laws or regulations.

ii) Peoples who are regarded as indigenous on account of their descent from the populations which inhabited the country, or a geographical region to which the country belongs, at the time of conquest or colonization or the establishment of present state boundaries and who, irrespective of their legal status, retain some or all of their own social, economic, cultural and political institution (ILO, 1989, www.ilo.org, 2021).

Thus, "indigenous communities, peoples and nations are those which, having a historical continuity with pre-invasion and pre-colonial societies that developed on their territories, consider themselves distinct from other sectors of the societies now prevailing in those territories, or parts of them. They from at present non-dominant sectors of the society and are determined to preserve, develop and transmit to future generations their ancestral 
territories, and their ethnic identity, as the basis of their continued existence as peoples in accordance with their own cultural patterns, social institutions and legal systems" (UN Resources Kit, 2008).

There are many types of knowledge in such indigenous peoples practiced from ancient period of time. Regarding this, ISDR (2008) defines that, indigenous knowledge refers to the methods and practices developed by a group of people from an advanced understanding of the local environment, which has formed over numerous generations of habitation. This knowledge contains several other important characteristics which distinguish it from other types of knowledge. These include originating within the community, maintaining a nonformal means of dissemination, collectively owned, developed over several generations and subject to adaptation, and imbedded in a community's way of life as a means of survival (ISDR, 2008).

Environment Conservation is not only concerning to Nepal. It is global issue and it is also an important factor of ecological balance. Population pressure, global warming, pollution, natural calamities have threats on environment. Pollution is a problem related to the increase in the world population and rapid raise of technology up until the $20^{\text {th }}$ century the problem of pollution was not really serious (Lekhak \& Lekhak, 2003). The human encroachment on the natural resources was early from the period but after Second World War the sharp development of industrialization, environment and natural resources are worthily effected (Adhikari \& Ghimire, 2003). Those activities remained the naturalism of Rousseau, which rejects everything beyond nature and ideal values which are manmade (Collinson, 2000).

The people who are eager to radical change and motivated with westernization, they are rushing towards the physical facilities. To seeking for physical facilities, mobility is a common feature in the human history. Central Nepal has been a region subjected much to the influence of its inhabitants since about 200 years ago (Adhikari, 2000). But its rule has become crucial recent times because of less economic opportunities and less facilities in the hilly region. In the process of modernization and economic development, naturally human show the tendency of migration where different facilities are possible. On the consequence rural areas are urbanizing haphazardly. Then the agriculture productive paddy fields are converting into towns as well as concrete jungles.

Human beings are going ahead to promote their economic and standard of living. Due to the development of science and technology population growth and their necessities are growing day by day. Industries are being established mainly to fulfill the human's needs. The natural resources like fossil fuels, forests etc. are being consumed as raw materials, 
their uses have been felt as uncontrolled and unsustainable manner. This consumption pattern has caused the environment degradation which is occurred as the main crisis in the world. In other word, land pollution, air pollution, water pollution etc. are the main causes global warming and climate change throughout the world.

Now, the climate change has become a burning but global issue. It has affected the world as a whole; although climate change is natural process, anthropogenic factors have its main cause in changing climate on this scale which has never observed before. In the context of Nepal farmers could not plant their rice in time. The snow in the Himalayas is melting day by day. The mountains of Nepal are being uncovered and black stones of mountains are been seen. When observing a global context, a report released by Asian Development Bank (ADB, 2009), mentions that more than 1.6 million people of South Asia could face acute water and food shortages from the melting of Himalayan glacier as a result of climate change. As Nepal is a developing country which contributes only the 0.025 percent of greenhouse gases emissions. Pollution elucidated by more than 200 Nepalese is equal to pollution initiated by one American. But America is not agreeing to sign in carbon reducing proposal. Other countries like china, India, Japan, and European countries are considered as big contributors (Mahato, 2064 BS). American's dominance practice enabled to read Foucault's power theory which imposed powers over others (Ritzer, 2000 \& Magee, 2001).

It is evident that global warming poses a serious threat to life on earth. Although scientists are unclear about the exact implications of global climate change most experts agree that plant communities, tropical landscapes, wildlife habitat, sea levels, weather patterns, and human mortality would be negatively impacted, In fact there might be some serious under estimations in the assumptions of the impacts of global warming which will cause significant damage to the earth and the human community (Mahat \& Belbase, 2064 BS). By this horrible impact the poorest countries and most vulnerable citizens will suffer the earliest and most damaging setbacks, even though they have contributed least to the problem. This situation is related with Darwin's theory of natural selection i.e. in the struggle of environment the creature will exist and the weak are vanished from this world (Dutta, 1982 \& Ritzer, 2000).

\section{Objective}

The objective of this study is to explore the uses of indigenous knowledge in conservation of environment and natural resources. 


\section{Methods and Sources of Data}

The qualitative approach was adopted according to the nature of objective (Creswell, 2012). Likewise information collection tools were developed interview guidelines and observation checklist. Informants were selected by purposive sampling method because the study needed experts who are well known about the study area. Sometimes followed snowball sampling i.e., as necessary (Kitchen \& Tate, 2000). This paper has applied descriptive and interpretive methods of study. The data form the secondary sources like reports, working papers, journals and books have been reviewed, analyzed and interpreted descriptively.

\section{Results}

\section{Application of Indigenous Knowledge in Environment Conservation}

Nepal is a country inhabited by various caste/ethnic groups many of whom have a distinct culture and language of their own as well as different religious persuasions (Nepali, 2007).

Moreover caste group or indigenous people live from the north to the south of Nepal. Bhattachan (2007) asserts that indigenous people are scattered in the hill, mountain and Terai region. Tamang et al. 1994 cited on Bhattachan (2008), mentioned that those communities which possess their own distinct tradition and original lingual and cultural traditions and whose religious faith is based on ancient animism (worship of ancestors, land, season, nature).

These various community based strategies have effectively protected and managed local natural resources, particularly lands and forests for their generations (Gurung, 1996). Indigenous knowledge is dynamic, the result of continuous process of experimentation, innovation and adaptation. It has capacity to argue with knowledge based on Science and technology (Gurung, 2009 \& Grenier, 1998).

Grenier adds further as indigenous knowledge is stored in peoples' memories and activities and in expressed in stories, songs, folklore proverbs, dances, myths, cultural values, beliefs, rituals, community laws, local language and taxonomy, agricultural practices, equipment, plant species and animal breeds. Some indigenous/ traditional knowledge regarding environment conservations which can be observed in many indigenous peoples' community are as follows:

\section{i) Ethno Pest Management in Mewahang Rai and Other Communities}

The Mewahang Rai have indigenous methods of pest management that are heavily 
relied on in areas where inputs (e.g. chemicals, pesticides) are in short supply. In remote areas, common pests such as stem borer (chilozonellis) attack wheat and maize stocks. The grounded pulp of the Khira leaf is spread on the wheat crop and the scent of the pulp is sufficient to kill the pests.(Local Name: Khira/ Khirro , Botanical Name: HolarrhenacPubsecens) (www.un.org, 2016). In the case of paddy, the pulp is introduced into the paddy field through the irrigation channel. In the case of specific pest attacks, like the rice moth which creates clusters of rice on paddy, they are combed out with sticks and the moths deposited in the water; to ensure decomposition, the operation is carried out in sunlight. In maize, the dried disease-infected stalks are manually removed. This knowledge helps to avoid the use of pesticides and also helps to balance the environment. Other indigenous communities Limbu, Magar, Newar, Yakhkhaa, Sunuwar also practice this methods of ethno pest management and ethno medicinal uses for antidiarrheal, wormicities, fishing purposes since ancient period.

\section{ii) Permit from Community Leader for Cutting Down Trees (Singi Nawa) in Sherpa Community}

This is one of the important community levels Indigenous knowledge of himanlayan Sherpa people, living in the highest part of the world to conserve the forest and wildlife. "Singi", in Sherpa language, means wood or trees and "Nawa" means to ask. So "Singi Nawa" means to ask someone before cutting any tree or wood (Sherpa, 2005). This is a custom the Sherpa have been practicing for many years. People choose a leader, senior but an intellectual person, among them who can perfectly handle the community. The leader prepares a calendar, where it is mentioned that people are allowed to cut trees on that date only otherwise some dreadful things may happen in the community. The people of the community ask the leader when they are allowed to cut trees. Because of him, the people maintain their discipline and do not cut trees anytime. This, in the long run, conserves the forest and balances the environment.

\section{iii) Watershed Management and Water Sources Cleaning in 'Si:thi Na:kha' Festival of Newar Community}

Watershed management is also one of the indigenous knowledge practiced by almost all hill communities of Nepal which helps in the conservation of forest as well as keeping the source of water clean. People have the belief that they should not cut trees or woods surrounding the source of water. They should not throw litter around the watershed. If they do not obey, bad results may occur to them. This tradition or beliefs preserves the forest as well as it preserves and keeps the source of water clean (ICIMOD, 1994). This is still practiced nowadays in the rural area of the country. 
Various sources of water like well, pond, tap (Hiti in Newari) are cleaned on the occasion of 'Si:thi Na:kha' celebration. Community members (Shrestha, 1994) voluntarily gather in the water sources and start refreshing all the water sources nearby the community by cleaning and maintenance if needed and worship. Then festival is celebrated by gathering, eating lentil bread or Bara (Wa: in Newari) (Source: personal communication with Shankha Shrestha (name changed); Aged 70 of Gokarneshwor)

\section{iV) Using Bitter Leaves (Titepati) for Herbal Medicine and Religious Rituals in Tamang}

"Titepati" is plant meaning bitter leaves in Nepali language. It is also an effective IK at national level. This plant is used almost all communities in the Nepal and south asian region. It is small green plant found in mostly hilly areas and used as herb for many kinds is diseases. It is used as paste for any cuts or bruises. It is also used as a cleaning agent. In Tamang community, this herb is essential from the birth to death. It is used to spray the holy water to ancestral deities and purifying the each objects and people as well (Source: Personal Communication with Ram Bahadur Tamang (name changed); aged 68 of Sundarijal). So that Tamang people grow "titepati" nearby their settlement which maintains the environmental balances (ICIMOD, 1994).

\section{V) Weed Controlling by (Natural Process) Sun Exposing and Irrigating as Traditional Practice of Most of the Indigenous People.}

Fields are ploughed approximately fifteen days before planting in the belief that exposure to the sun will kill the weeds. During intercultural operations, manual weeding is carried out and burning is still prevalent. On rain fed field, flooding through irrigation is carried out for effective weed control (Sherpa, 2005). This kind of Traditional knowledge is also in practice almost all parts of Nepal.

\section{Customs and Religion in Environment Conservation}

Indigenous peoples' knowledge are being practiced on their customs and rituals too which helps environment conservation directly or indirectly. Further, the paragraphs below discuss on the Indigenous knowledge that is one or in other way displays environment conservation.

\section{Customs in Conservation}

In the wedding ceremony, Chepangs give a Chyuri tree (an indigenous fruit tree) growing nearby as a dowry to their daughters (Bista, 2000) which help to plant and conserve the 
trees. Bista explore mere for the Gurungs costumes/rituals. They build Chautara and plant trees on it for resting along a main trail in the name of dead relative. Also dig a small water pond for cattle beside it. Many other build similar resting places in order to acquire merit. Not only Gurungs but also Tamangs preserve trees on the crematory. Plant and preserve trees at water resources (Pandhero) and both sides of the ways. They believe that to destroy those plants are sinful acts. As they are naturalistic, they worship to nature i.e. stone, trees, jungles, earth etc. Their phenomena remembered me the hermeneutics which concern the interaction of human history (Ritzer, 2000).

Dhimal and Boda worship DIN (the god of rain) every day within their house. The god $D I N$ himself pours water from the sky (Bista, 2000). As the Aryan use various Vedas and Upanishad in various purpose, the Kirats also do the same in this concern. It is such guidline which is followed, in every socio-cultural rite such as life, birth, death, religion, methods of farming, animal husbendry, methods of worship and ritual perfection. Rai perception of the environment is influenced by the creation of myth, a distinct part of the Mundhoom of oral tradition (Gurung, 1994). The cultivation of land showing and harvesting with due devotion of God is found given. Regarding this Khatri (2005) mentions that, different species of plants and animals related with life support are also mentioned in this oral code. Khatri adds more, the Kirats claim themselves to be guiding by Mundhoom from the ancient period seems to be proved from conservation of biodiversity.

Shrestha (1998) noted that Indigenous knowledge is based on nature. Nepali villagers believe the cuckoo birds sings "Kaphal Pakyo" the Kaphal fruit is ripe and the "biubiu" cry another bird is a warning that the seeds are rotting. The rural life style follows the rhythm of nature and human beings are seen to be a part of nature.

\section{Religious Practices in Environment Conservation}

An indigenous knowledge generation is also related with religion, because our culture is deeply rooted with different religious.

\section{i) Hinduism Related Practices in Conservation}

Hinduism has a very close relation with environment. A Hindu worships various manifestations of nature, such as sun, moon, river, air, soil, stone etc. as gods and goddess. Brahma has been regarded as the creator of the Universe under different names, forms and attributes given to him in the Vedas, Upanishads and Purans (Shrestha, 1998). According to Hindu religion-which sustain all the species of life and helps to maintain harmonious relationship among them is Dharma and that which disturbs such ecology is adharm (WWF, 2000). Also, Bhagawat Gita a dialogue between Sri Krishna and Arjuna which is 
a clear and precise life science. It is narrated that a life without contribution towards the preservation of ecology is a life of a sin. The Hindu people believe different plants such as Pipal, Bar, Tulsi etc. are the different forms of god/goddess. So they plant, conserve and worship those plants. The practice is helpful to reduce green-house gases like carbon dioxide, sulphur dioxide.

\section{ii) Buddhist Practices in Environment Conservation}

Buddhism also has very close relationship with environment. One of the principles of Buddhism is nonviolence. We can relate this to conservation of biological diversity. Early Buddihsm believe in a close relationship between human morality and the natural environment (Shrestha, 1998). He further states Pipal is acknowledged as a Bodhi tree, under which Buddha is said to have attained enlightenment.

Buddha's preachings taught men to live simply and to cherish tranquility by appreciating the natural cycle of life. Nature is and ecosystem in which trees affect climate, the soil and the animals, just as the climate affects the trees, the soil, the animals and so on (WWF, 2000). Maha Ghosananda said, "When we respect environment, then nature will be good to us. When our hearts are good, then the sky will be good to us. The trees are like our mother and father they feed us and provide everything. So we spread the dharma (truth) of protecting our selves and protecting our environment, which is dharma of the Buddha (Ibid).

\section{iii) Islamic Practices in Conservation Environment}

Islam is considered as monotheistic religion. It is a system of belief and practices established by Prophet Mohammad. According to Islam, all of the resources up on which life depends have been created by god. In Islam, the utilization of resources is the right and privilege of all people and species (Shrestha, 1998). Each generation uses and makes the best use of nature, according to its need, without disrupting or adversely affecting the interest of future generations. Therefore, Islam says that human being should not abuse, misuse, and damage the natural resources since each generation is entitled to benefit from them (Ibid).

Another principle which underpins Islamic commitment to the conservation of nature and natural resources is the principle of divine ownership of all that exists on earth and in the heaven animate and inanimate (WWF, 2000). The institutions enhanced more different principles all taken from Islam's ultimate authority, the Holy Quran-set the perspectives of the relationship of human being to god and of god to Environment in its totality. 
Regarding this, Indigenous knowledge are generated from different religions as mentioned above. But due to western knowledge those moral and indigenous knowledge are been suppressed. Western knowledge is developmental as well as modernization oriented. Which remembered me Weber's modernization theory; which enhances that the transformation of traditional societies into industrial societies (Henslin,1997). Likewise, Haralumbus (2003), mentions that modern development is directly related with industrialization, which aim is to earn profit and this is related with Marx capitalism theory; enhance up on how this class division works out under capitalism, the economic system of modern societies (Ritzer, 2000).

\section{Discussion}

The modern knowledge made people to think on various options. So people promoted to lose their traditional culture and knowledge. The issue is related with post-modernism theory. According to Derrida, it is the view of deconstruction of exist society (modern society), such as "the deconstruction of logocentrism" (Ritzer, 2000). Modern knowledge ultimately replaced our knowledge/culture by western knowledge and culture. According to Spybey's (1992) colonialism theory, the destruction of indigenous ways, to the use of more hegemonic means, such as the application of foreign colonial norms which have corroded local values and traditions. Similarly, Henslin (1997) enhance that, colonialism refers to how the most industrialized nations exploit the least industrialize nations.

Different experts and scientists have proved that plants are one of the components of environment. There are autotrophic of nature which manufactures their food using carbon dioxide $\left(\mathrm{CO}_{2}\right)$ and water with the help of chlorophyll in the presence of sunlight. Then produce carbohydrate and liberate oxygen which is essential for respiration to all living beings. Plants are the sources of fuel, fodder, timber, medicine etc. Different saints and scientists have explained different views of significant of the forest (Hada, 2064 BS). As discussed obviously the environmental cleaner the forests are being devasted through modern developmental practice and economic development competency of the world people. The voices of its conservation are also arising consequently. The Modern educationist and scientists are making people awareness through school education and different institutions. But rather it is not fruitful of achieving the goals. So my view is that it is necessary to promote indigenous knowledge and practice for plant conservation as well as environment conservation.

The traditional knowledge of plant conservation was only dieties of God/Goddes and ritual believes. But western knowledge/ science proved that it observes $\mathrm{CO} 2$ gas and 
release O2 in the process of photosynthesis (Dutta, 1982). In eastern, the health check was depended on pulse beating but western/scientific knowledge brought video X-rays, Operation treatments are effective. They manufactured medicines which are easy to use. Those technical knowledges are developed from the eastern philosophical knowledge.

The modernization is divesting the environment badly and modern education and practices are also not successful to conserve it. The community forestry programme is effective for preserve the trees but it is not completely western. In evidence our village has a bushed jungle named as Banpala but there is no big jungle. By this we can say the forest conservation concept and practice was from early period. Hobley (1990) asserted that Laxman Dong (Tamang) and his family of Sindhupalchok, Banskharkha have a great credit for conservation of community forestry .

The adverse effects of environment on living beings prove Newton's Third Law of Motion. The law: every action is equal and opposite of reaction. In the same way as man destroyed environment during this century, environment has started killing man and other living beings (Dani, 1996). In this developmental race, we cannot ignore the modern technological development. A marriage of traditional and modern scientific knowledge is necessary to solve the problems of poverty and environmental deterioration (Gurung, 1994). The fusion knowledge remembered me Darrida's postmodernism theory which is opposing to see the reality in classical perspective but argues to see in the different lenses.

In addition to, indigenous knowledge system is critical factor for sustainable development. Empowerment of local communities is a prerequisite for the integration of indigenous knowledge in development process. The integration of appropriate indigenous knowledge systems into development programs has already contributed to efficiency, effectiveness, and sustainable development impact. Indigenous knowledge, like any other knowledge, needs to be constantly used, challenged, and further adopted to the evolving local contexts. Supporting local and regional networks of traditional practitioners and community exchange can help to disseminate useful and relevant indigenous knowledge and to enable communities to participate more actively in the development process. While innovative mechanisms for the protection of indigenous knowledge need to be developed, many indigenous knowledge practices can at the same time be integrated into local, national, regional, or even global efforts.

Aaya and Wasna (2016) also asserted that the indigenous knowledge systems in Africa were a significant resource which would contribute to the increased efficiency, effectiveness and sustainability in environmental conservation among rural communities of developing countries in particular. Further they adds indigenous knowledge systems 
form the basis for community-level decision making in areas pertaining to food security, human and animal health, education and more important in natural resource management. However, despite their critical role in the conservation of the bio-physical environment, these practices and technologies are being marginalized or even forgotten among rural communities in different parts of the world. In this regards UNEP (2021) has published a story about Amazon which focuses on that there is absolute need to protect, preserve and promote the traditional knowledge, customary sustainable use and expertise of indigenous communities if people want to halt the damage and ultimately save themselves.

\section{Conclusion}

Nepalese society is full of diversity and also rich in biological diversity. Diversified community possesses many knowledge and skills derived from repeated practices from generation to generation. Indigenous knowledge has been the way of living which are directly associated with culture and traditions of the people residing from ancient period of time. These knowledge are applicable in day to day lives of people. Production, utilization and conservation of natural resources and environment play important role in livelihoods of indigenous people. Most of the indigenous people applied the indigenous knowledge system in the name of custom and religion which ultimately conserved the nature knowingly and unknowingly both way (Gurung, 2018). There is need of identification of indigenous knowledge and scientific verification as well. The application of indigenous knowledge and practice on natural resource management not only protect environment in the world but also conserve social culture, religion and ecofriendly society.

\section{References}

Adhikari, J. (2008). Changing livelihoods. Essays on Nepal's development since 1990. Kathmandu. Martin Chautari, Nepal.

Adhikari, J., \& Ghimire, S. (2003). Environmental justice resource collection. Kathmandu. Martin Chautari, Nepal.

Ayaa, D. D., \& Waswa, F. (2016). Role of indigenous knowledge systems in the conservation of the bio-physical environment among the Teso community in Busia County-Kenya. African Journal of Environmental Science and Technology, 10(12), 467-475.

Bhattachan, K. B. (2008). Minorities and indigenous people of Nepal. National coalition against Racial Discrimination, Kathmandu, Nepal.

Bhattachan, Y. K. (2007). Democratic Practices of Nepal. Democracies in the indigenous 
organizations of Nepal. Nepal Centre for Creative Research, Kathmandu, Nepal.

Bista, D. B. (2000). People of Nepal. Ratna Pustak Bhandar, Kathmandu. Nepal.

Collinson, D. (2000). Fifty grate philosophers. Croom Helm Ltd., London.

Creswell, J. W. (2012). Qualitative inquiry \& research design: Choosing among five approaches (4th ed.). Thousand Oaks, CA: Sage.

Creswell, J. W. (2012), Research design, qualitative, quantitative and mixed methods approaches ( $3^{\text {rd }}$ ed.). New Delhi: Sage publications India Pvt. Ltd.

Curriculum Development Centre (CDC). (2058). Curriculum for secondary level \& lower secondary level. Sanothimi, Bhaktapur, Nepal.

Dani, H. M. (1996). Environmental education. Scientific, social and legal aspects. Publication Bureau.

Giddens, A. (2000). Sociology. AITBS Publication and Distributor, Delhi, India.

Giri, S. K. (2065). Hamro kalpabrikchha, 203. Department of Forest, Kathmandu, Nepal.

Government of Nepal (GoN), \& Ministry of Forests and Soil Conservation (MoFSC). (2014). Nepal biodiversity strategy and action plan 2014-2020. Government of Nepal, Nepal.

Grenier, L. (1998).Working with indigenous knowledge. International Development Research Centre, Canada.

Gurung, G. P. (2018). Educational perspective of indigenous knowledge and practice of plant management of Gurung Community. PhD Thesis (Unpublished), Faculty of Education, TU.

Gurung, J. D. (1994). Indigenous knowledge systems and biodiversity management. Kathmandu, ICIMOD, Nepal

Gurung, O. P. (1996). Customary system of natural resource management among Tarami Magars of western Nepal. A dissertation presented to the faculty of the graduate school of Cornell University in partial fulfillment of the requirements for the degree of Doctor of Philosophy.

Hada, G. B. (2064), Hamro Kalpa Briksha. Importance and essential of forest resource in Nepal, Department of Forest.

Haralumbus, M. (2003). Sociology: Themes \& perspectives. Oxford University Press, India. 
Henslin, J. M. (1997). Sociology: A down- to-earth approach. $3^{\text {rd }}$ ed. London.

Hobley, M. P. (1990). Social reality, social forestry: The case of two panchayats, PhD Thesis The Austrilian NationalUniversity, Austrilia .

International Labour Organization (ILO). (1989). C169-indigenous and tribal peoples convention 189 (No.169). https://www.ilo.org/dyn/normlex/en/f?p=NORMLEX PUB:12100:0::NO::P12100_ILO_CODE:C169

International Strategy for Disaster Reduction (ISDR). (2008). Indigenous knowledge for disaster risk reduction: Good practices and lesson learned from experiences in the Asia-Pacific Region, Bankok, Thailand.

Karki, U. B. (1998). Environmental education source book for bachelor of education programme. Kathmandu, Nepal.

Khatri, N. K. (2005). Conservation of biological diversity (plants and animals) in legal aspect of Nepal: Historical Study. Doctoral dissertation, Tribhuvan University.

Kitchin, R., \& Tate, N. J. (2000), Conducting research into human geography: theory, methodology and practice. Prentice Hall, London

Lekhak, H. D., \& Lekhak, B. (2003). Natural resource conservation and sustainable development in Nepal. Kshitiz Publication, Kathmandu, Nepal.

Mahat, T. J., \& Belbase, L. (2064). Hamro kalpabrikchha. Promoting forestry for low carbon society, 201. Department of forest, Kathmandu, Nepal

Mahato, H. C. (2065). Hamro kalpabrikchha, Scope and pinus, 201. Department of Forest, Kathmandu, Nepal.

Ministry of Forests and Soil Conservation (MoFSC). (2014). Nepal biodiversity strategy and action plan 2014-2020. Ministry of Forests and Soil Conservation, Government of Nepal, Kathmandu, Nepal.

Nepali, B. (2007). Essence and challenges of special provisions for dalit inclusion. Kathmandu: NNDSWO.

Regmi, R. K. (2003). Sustainability of lasting fuel, forum for sustainable development Nepal. Forum for sustainable development, Nepal.

Ritzer, G. (2000). Sociological theory. (Fifth Ed.). McGraw-Hill International, New Delhi.

Sherpa, N. S. (2005). Indigenous peoples of Nepal and traditional knowledge; workshop paper presented on international workshop on traditional knowledge. Department 
of Economic and Social Affairs, United Nations, New York.

Shrestha, U. (1998). Environmental education source book for bachelor of education programme. Hinduism and environment. Kathmandu, Nepal.

Subedi, R. R. (2008). Shikchha, education journal. Curriculum Development Centre, Government of Nepal, Nepal.

United Nations (UN). (2008), Resource kit on indigenous peoples' issues. Department of Economic and Social Affairs, New York.

United Nations Environment Programme (UNEP). (2021). Champion of the earth: How indigenous knowledge can help prevent environmental crises. Environmental Rights of Governance. https://www.unep.org/news-and-stories/story/how. .

Woods, T. (2007). Beginning post modernism. Manchester University Press, New York.

World Wide Fund (WWF). (2000). Religion and conservation. World wide Fund for Nature, India. 